\section{INHIBITORY EFFECT OF NEW ANTIBIOTIC, PRADIMICIN A ON INFECTIVITY, CYTOPATHIC EFFECT AND REPLICATION OF HUMAN IMMUNODEFI- CIENCY VIRUS IN VITRO}

Sir:

Pradimicin A (Fig. 1) has been found as a new antifungal antibiotic in the culture filtrate of Actinomadura hibisca sp. nov. Strain P157-2 (ATCC 53557). ${ }^{1 \sim 3)}$ In this communication, we describe that the antibiotic and its imino derivative efficiently inhibit the human $\mathrm{T}$-lymphotropic virus type IIIB (HTLV-IIIB)-induced cyctopathic effect of MT-4 cells and the cell fusion by cell to cell infection and syncytia formation in the cocultures of MOLT-4 and MOLT-4/human immunodeficiency virus (HIV) HTLV-YIIB $_{\text {cells. }}$

The number of viable MT-4 cells infected with HIV at a multiplicity of infection of 0.002 decreased during the cultivation and almost all cells were dead by 6 days after infection as determined by a trypan blue dye exclusion method.") When pradimicin A (1) and imino derivative (2) were added to the culture, the cell damage induced by HIV was significantly suppressed at the concentrations more than $3.5 \mu \mathrm{g} / \mathrm{ml}$ of compounds (Fig. 2). With regard to cytotoxicity of $\mathbf{1}$ and 2, almost no growth inhibition of MT-4 cells was observed at the concentrations up to $30 \mu \mathrm{g} / \mathrm{ml}$. Higher concentrations of 1 and 2 showed only weak growth inhibition against MT-4 cells.

Fig. 1. Chemical structures of pradimicin A and its imino derivative.

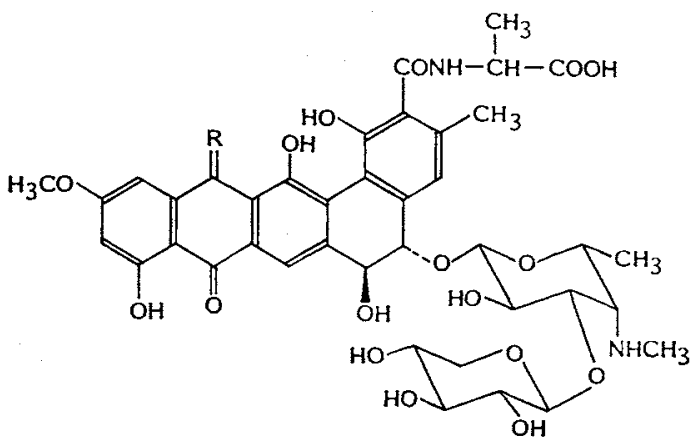

Pradimicin A (1) $\quad \mathrm{R}=\mathrm{O}$

Fig. 2. Effect of pradimicin A (A: day 3, B: day 6) and imino derivative (C: day 3, D: day 6) on the cell growth of MT-4 cells (open bars), and inhibitory effect on the virus-induced cytopathic effects in HIVinfected MT-4 cells (shadow bars).

(A)

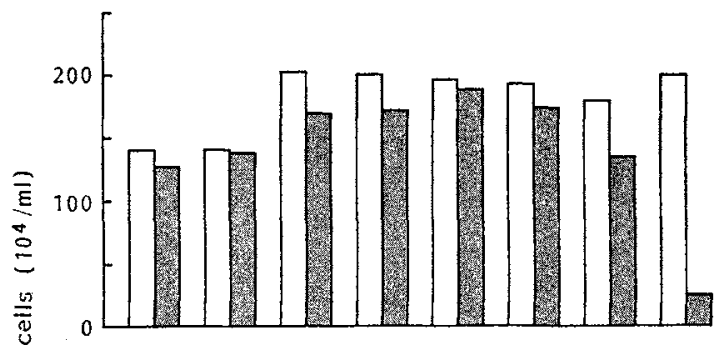

(c)



(B)

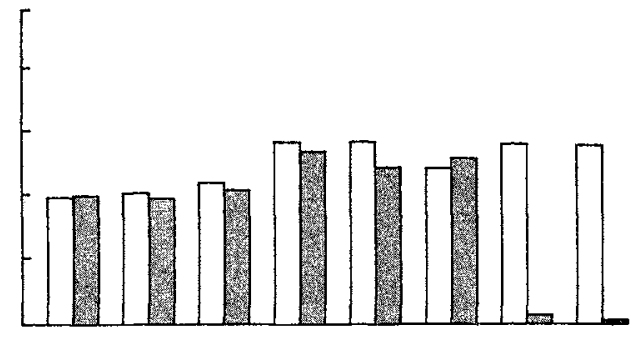

(D)

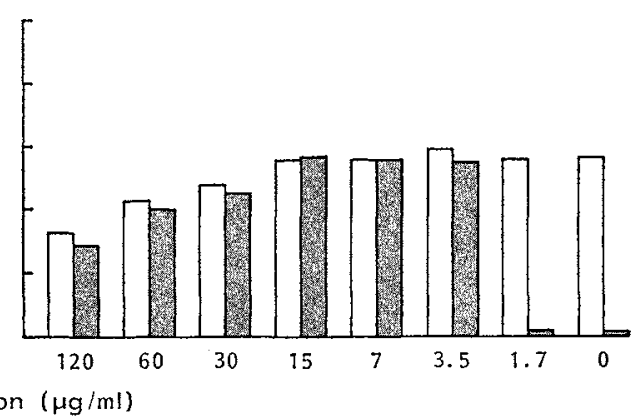


Fig. 3. Effect of pradimicin A and its imino derivative on HIV-induced multinucleated giant cell formation in cocultures.

(A)

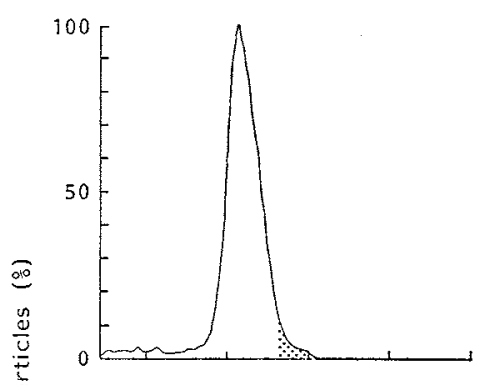

(D)



(B)

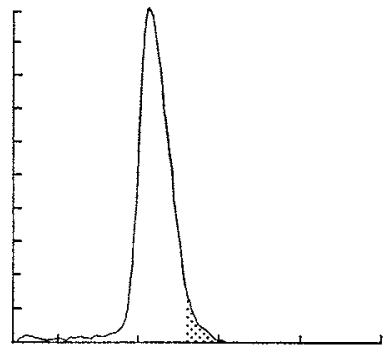

(E)

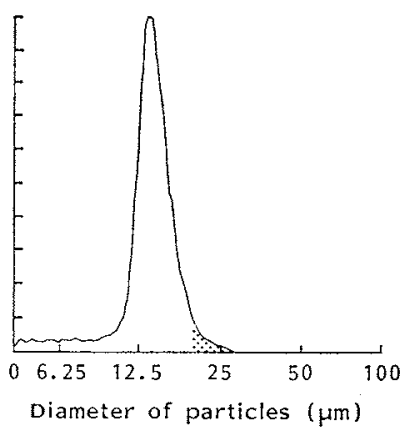

(c)

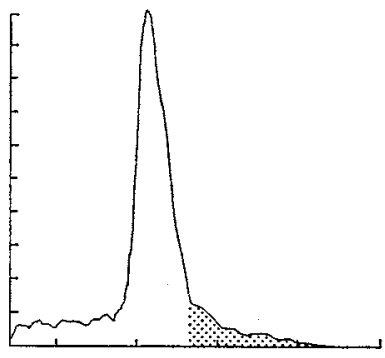

(F)

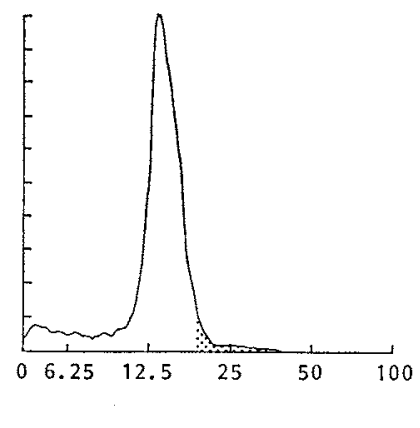

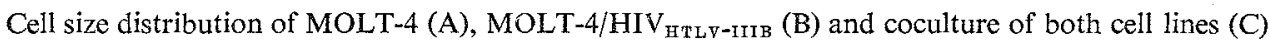
was analyzed by a cell multisizer. A portion of particles with more than $20 \mu \mathrm{m}$ in diameter was dotted. Effect of dextran sulfate (D), pradimicin $A(E)$ and imino derivative (F) was examined at the concentrations of $50 \mu \mathrm{g} / \mathrm{ml}, 25 \mu \mathrm{g} / \mathrm{ml}$ and $25 \mu \mathrm{g} / \mathrm{ml}$, respectively.

Experssion of HIV antigen as revealed by immunofluorescence was significantly suppressed when HIV-infected MT-4 cells were cultured in the presence of 1 and 2 , and positive cells were only less than $1 \%$ at the concentrations more than $3.5 \mu \mathrm{g} / \mathrm{ml}$ of both 1 and 2 (data not shown).

We next inquired the effect of these compounds on the multinucleated giant cell formation. MOLT-4 and MOLT-4/HIV mixed in a $1: 1$ ratio in proportion of cell number and incubated for 20 hours at $37^{\circ} \mathrm{C}$. Then the size of particles was measured and the diameter was plotted on the horizontal axis by a cell multisizer. ${ }^{5)}$ Fig. 3 shows the results obtained by a cell multisizer in cocultures added at $25 \mu \mathrm{g} / \mathrm{ml}$ of 1 and 2 or $50 \mu \mathrm{g} / \mathrm{ml}$ of dextran sulfate used as a positive control. The percentage of cell particles with more than $20 \mu \mathrm{m}$ was only $2.7 \%$ and $2.4 \%$ in MOLT-4 cells and MOLT-4/HIV ${ }_{\text {HTLV-IIIB }}$ cells, respectively. On the other hand, in the coculture of both cell lines the frequency of cell particles with more than $20 \mu \mathrm{m}$ in diameter was
$11.8 \%$. When 1 and 2 were added to cocultures, giant cell formation was apparently suppressed at the concentrations more than $12.5 \mu \mathrm{g} / \mathrm{ml}$.

The viable cells in each culture were also counted and the fusion index (FI) value was calculated as described previously. ${ }^{6)}$ Control culture without compound showed the FI value of 1.71. The FI value of the culture containing $50 \mu \mathrm{g} / \mathrm{ml}$ of dextran sulfate, which completely inhibitied the giant cell formation, was 0.12 and the culture containing $50 \mu \mathrm{g} / \mathrm{ml}$ and $25 \mu \mathrm{g} / \mathrm{ml}$ of 1 and 2 showed the FI value of less than 0.2 (data not shown).

1 and 2 did not inhibit avian myeloblastosis virus (AMV) reverse transcriptase $(1 \mathrm{U})$ even at the concentration of $100 \mu \mathrm{g} / \mathrm{ml}$ (data not shown).

From the results 1 and 2 showed the anti-HIV activity at the concentrations more than $3.5 \mu \mathrm{g} /$ $\mathrm{ml}$ in the cell-free infection with MT-4 cells. More importantly, they showed inhibitory activity to the HIV-induced giant cell formation at the concentrations more than $12.5 \mu \mathrm{g} / \mathrm{ml}$ in coculture 
system. In the presence of 1 or $\mathbf{2}$ size distribution pattern of cells in the cocultures was similar to that in the culture with dextran sulfate used as a positive control (Figs. 3D 3F). On the other hand, these compounds did not inhibit the AMV reverse transcriptase. These results strongly suggest that 1 and 2 exert their anti-HIV activity on the step of viral adsorption.

1 and 2 are shown to have antiviral activity against influenza virus. ${ }^{2)}$ Very recently, TAKEUCHI et al. also reported that benanomicin, ${ }^{7)}$ which has closely related structure to $\mathbf{1}$, was active against fungi and some Gram-positive bacteria. At present we do not know the reason why 1 or benanomicin is active against such various species of microorganisms.

1 and 2 scarcely inhibited the growth of MT-4 cells and chemotherapeutic indices showed relatively large. Therefore, it is worthy to study these compounds more extensively in terms of chemotherapeutic and/or prophylactic point of view against AIDS and ARC.

\section{AKIKo TANABE HideKi NAKASHIMA OSAMU Yoshida NAOKI YAMAMOTO}

Department of Virology and Parasitology, Yamaguchi University School of Medicine, 1144 Kogushi, Ube, Yamaguchi 755, Japan

\section{OSAMU TENMYo TOSHIKAZU OK}

Bristol-Myers Research Institute, Ltd., Tokyo Research Center, 2-9-3 Shimo-meguro, Meguro-ku, Tokyo 153, Japan

(Received July 18, 1988)

\section{References}

1) Konishi, M.; M. Tsunakawa, M. Nishio, H. Ohkuma, M. Hrrano, T. Miyaki, T. OKI \& H. KaWAGUCHI: A novel potent antifungal antibiotic, BMY-28567. Isolation, chemical and biological properties. Program and Abstracts of the 27th Intersci. Conf. on Antimicrob. Agents and Chemother., No. 984, p. 268, New York, Oct. 4 7, 1987

2) Oki, T.; K. Saitoh, K. Tomatsu, K. Tomita, M. Konishi \& H. KaWaguchi: Novel Antifungal Antibiotic BMY-28567: Structural Study and Biological Activitics. Annals New York Academic Science, in Press

3) OKI, T.; M. Konishi, K. Tomatsu, K. Tomita, K. Sattoh, M. Tsunakawa, M. Nishio, T. Miyaki \& H. KawaguchI: Pradimicin, a novel class of potent antifungal antibiotics. J. Antibiotics 41 : $1701 \sim 1704,1988$

4) Nakashima, H.; T. Matsui, S. Harada, N. Kobayashi, A. Matsuda, T. Ueda \& N. YAMAMOTO: Inhibition of replication and cytopathic effect of human $\mathrm{T}$ cell lymphotropic virus type III/lymphadenopathy-associated virus by $3^{\prime}$-azido-3'-deoxythymidine in vitro. Antimicrob. Agents Chemother. 30: 933 937, 1986

5) Nakashima, H.; A. Tanabe, T.S. Tochikura \& N. Yamamoto: Rapid screening method with a cell multisizer for inhibitors of human immunodeficiency virus-induced cell fusion in vitro. J. Clin. Microbiol. 26: 1229 1232, 1988

6) Tochikura, T.S.; H. Nakashima, A. TANabe \& N. Yamamoto: Human immunodeficiency virus (HIV)-induced cell fusion: Quantification and its application for the simple and rapid screening of anti-HIV substances in vitro. Virology 164: 542 546, 1988

7) Takeuchi, T.; T. Hara, H. Naganawa, M. Okada, M. Hamada, H. Umezawa, S. Gom, M. SEzaki \& S. Kondo: New antifungal antibiotics, benanomicins $\mathrm{A}$ and $\mathrm{B}$ from an Actinomycete. J. Antibiotics 41:807 811, 1988 